\title{
Identification of a New Antigen Epitope in the Nuclear Localization Signal Region of Porcine Circovirus Type 2 Capsid Protein
}

\author{
Longjun Guo Yuehua Lu Liping Huang Yanwu Wei Changming Liu
}

Division of Swine Infectious Diseases, State Key Laboratory of Veterinary Biotechnology, Harbin Veterinary

Research Institute of the Chinese Academy of Agricultural Sciences, Harbin, PR China

\section{Key Words}

Capsid protein $\cdot$ Epitope mapping $\cdot$ Nuclear localization

signal $\cdot$ Porcine circovirus type 2

\begin{abstract}
Objective: Porcine circovirus type 2 (PCV2) is the causative agent of postweaning multisystemic syndrome in pigs. The capsid (Cap) protein encoded by ORF2 is the main structural protein involved in the host immune protective response to PCV2. It is therefore important to map the antigenic epitopes of the PCV2 Cap protein. Methods: In this study, 5 monoclonal antibodies (mAbs) against the recombinant PCV2 Cap protein, expressed by the baculovirus system in Sf21 insect cells, were generated. The antigenic epitope recognized by these mAbs was located in the Cap A protein by Western blot analysis using 4 overlapping minifragments covering the Cap protein expressed in Escherichia coli. To locate the epitope more accurately, 3 sets of overlapping peptides were synthesized. Results: The results demonstrated that 4 of the $5 \mathrm{mAbs}$ recognized the same core epitope $\left.{ }^{26} \mathrm{RPWLVHPRHRY}{ }^{36}\right)$ located in the nuclear localization signal (NLS) region at the $\mathrm{N}$ terminus of the Cap protein. The other mAb (1D2) reacted with the recombinant Cap protein only, indicating that it recognizes a potential conformational epitope. This mAb demonstrated a neutralizing effect on PCV2. Conclusion: This is the first study to identify an antigenic epitope in the NLS region of the PCV2 Cap protein us-
\end{abstract}

ing mAbs. The results of this study will facilitate future investigations into the mechanism and function of nuclear localization of this protein.

Copyright $\odot 2010$ S. Karger AG, Basel

\section{Introduction}

Porcine circovirus type 2 (PCV2) is recognized as the infectious agent of postweaning multisystemic wasting syndrome. Following the first confirmed case in Canada in 1997 [1-5], PCV2 has become a financial burden on the swine industry in North America, Europe and Asia. PCV2 is a member of the genus Circovirus, which belongs to the family Circoviridae, the smallest nonenveloped, single-stranded, circular DNA viruses that replicate autonomously in mammalian cells. The viral DNA of PCV2, which is encapsulated by a single viral protein, is a singlestranded negative-sense circularized molecule of 1,7671,768 nucleotides [6]. Its genome contains 3 major open reading frames (ORFs): ORF1, which encodes 2 replication-associated proteins (Rep and Rep') [7-9], ORF2, which encodes a viral capsid (Cap) protein involved in the host immune response [10,11], and ORF3, which encodes a protein contributing to virus-induced apoptosis [12, 13]. Forty-one amino acids (aa) in the $\mathrm{N}$ terminus of ORF2, which encodes the Cap protein, were associated with localization of the Cap protein in the nucleus, of

Changming Liu, DVM, PhD, Division of Swine Infectious Diseases

State Key Laboratory of Veterinary Biotechnology

Harbin Veterinary Research Institute of CAAS

427 Maduan Street, Nangang Region, Harbin 150001 (PR China)

Tel. +86 4518593 5094, Fax +86 4518273 3132, E-Mail lcm@ @vri.ac.cn 
which aa $12-18$ and 34-41 were critical for localization of Cap in the nucleus [14]. Many studies investigating the potential functions of the PCV2 Cap protein have been reported [15-18]. Monoclonal antibodies (mAbs) against the Cap protein are important tools for investigating the antigen epitopes expressed on the protein. Two epitopes spanning aa residues $69-83$ and 117-131 have been identified as specific to the PCV2 Cap protein [19] and at least 5 different, but overlapping, conformational epitopes within aa residues $47-63$ and $165-200$ and the last 4 aa in the $\mathrm{C}$ terminus of the PCV2 Cap protein were located using chimeric PCV1 and PCV2 constructs [20]. Different antigenic epitopes expressed by different PCV2 isolates have been reported too $[21,22]$.

To study the PCV2 Cap protein and its potential prophylactic use, it is important to map the antigenic epitopes expressed on this protein, especially those located in the nuclear localization signal (NLS) region and those recognized by neutralizing antibodies. In this study, the epitopes were identified using $\mathrm{mAbs}$ and one new antigenic epitope located in the NLS region of the PCV2 Cap protein was detected.

\section{Materials and Methods}

\section{Preparation of $m A b s$ and Viruses}

Six-week-old, female, BALB/c mice were purchased from the Experimental Animal Center of Harbin Veterinary Research Institute (Chinese Academy of Agricultural Sciences, China). Mice were immunized intraperitoneally with $250 \mu \mathrm{g}$ of purified PCV2 recombinant Cap protein (PCV2-rCap), prepared using the baculovirus expression system in $0.5 \mathrm{ml}$ of emulsion with complete Freund's adjuvant. Two booster injections with the same dose of emulsion were then given at 2 -week intervals. One day after the last injection, the spleens were surgically removed from the mice. Five mAbs, designated $1 \mathrm{D} 2,2 \mathrm{E} 8,3 \mathrm{~A} 10,5 \mathrm{~F} 2$ and $6 \mathrm{~F} 10$, were prepared using the lymphocyte hybridoma technique. The $\mathrm{mAb}$ ascites titers reached $1: 2,048,000,1: 512,000,1: 1,024,000,1: 512,000$ and 1:1,024,000 for $1 \mathrm{D} 2,2 \mathrm{E} 8,3 \mathrm{~A} 10,5 \mathrm{~F} 2$ and $6 \mathrm{~F} 10$, respectively. The $\mathrm{mAb}$ isotypes were IgG2a for 1D2, 2E8, 5F2 and 6F10; and IgG1 for $3 \mathrm{~A} 10$. The $\mathrm{mAb}$ light chains were $\lambda$-chain for $2 \mathrm{E} 8,3 \mathrm{~A} 10,5 \mathrm{~F} 2$ and $6 \mathrm{~F} 10$, and $\kappa$-chain for 1D2. Western blot analysis showed that mAbs 2E8, 3A10, 5F2 and $6 \mathrm{~F} 10$, but not $1 \mathrm{D} 2$, reacted with native PCV2-Cap protein, indicating that the epitopes recognized by these $\mathrm{mAbs}$ are present within the mature virus particles (fig. 1). mAb 1D2 reacted to PCV2 protein in an immunoperoxidase monolayer assay and an antigen capture ELISA, and could be used to differentiate between PCV1 and PCV2 under the same conditions. mAb 1D2 was also able to neutralize PCV2 in a neutralization test (data not shown). Strain PCV2-JF (GenBank No. HM038022) was isolated and maintained in the pig kidney cell line (PK-15), which was PCV1 free. The truncated Cap peptides were designed according to the ORF2 sequence of strain PCV2-JF. Anti-PCV2-positive polyclonal swine sera and PCV2-negative swine sera were prepared in our laboratory.

Identification of a New Antigen Epitope in the NLS Region of PCV2 Protein

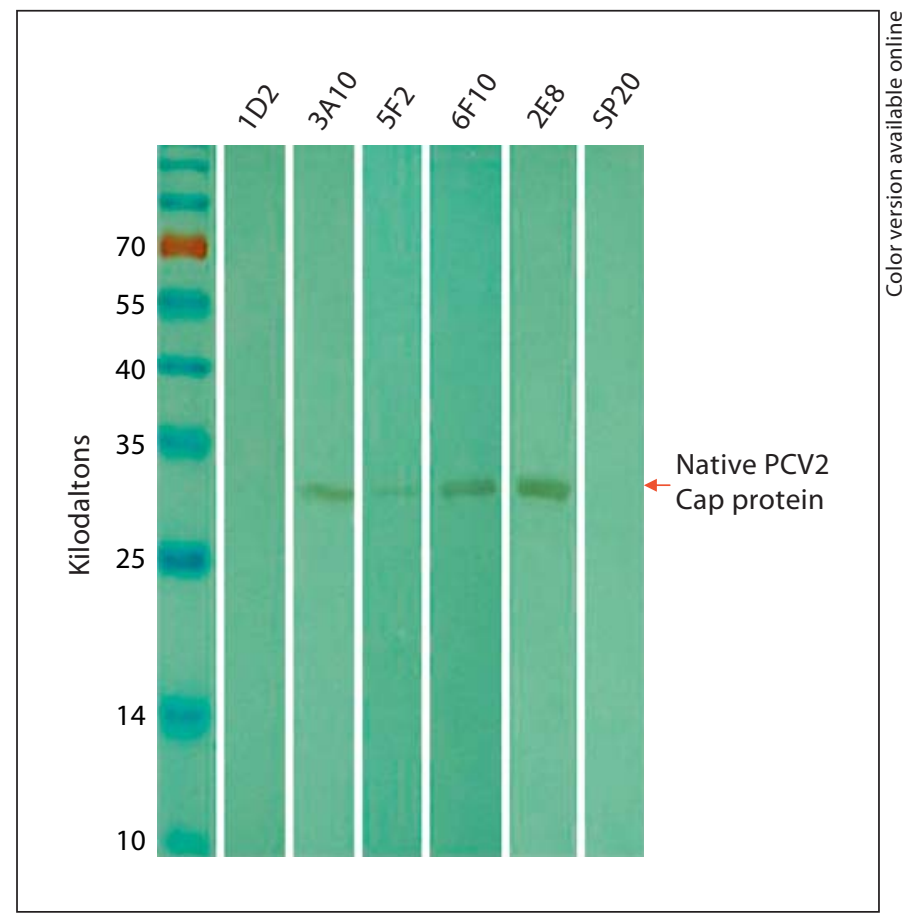

Fig. 1. Western blot analysis of the reactivity of PCV2 Cap protein to a range of $\mathrm{mAbs}$. Native virions from strain PCV2/JF were separated by SDS-PAGE, transferred to nitrocellulose membrane, and then incubated with mAbs. The mAbs and the SP20 control are indicated in the figure. Western blot analysis showed that mAbs 2E8, 3A10, 5F2 and 6F10 reacted with native PCV2 Cap protein (indicated by the arrow at approximately $30 \mathrm{kDa}$ ), but mAb 1D2 did not.

Primer Design, PCR Amplification and Construction of

Recombinant Expression Vectors Containing the Truncated ORF2 Genes

Four pairs of primers were designed from the DNA sequence of strain PCV2-JF which spanned the entire ORF2 gene and contained BamHI and XhoI restriction sites (restriction enzyme sites are shown in italics in table 1). The 4 overlapping PCR products amplified using these primer pairs were termed Cap A, B, C and D. PCR (using reaction components from Takara Biotechnology, China) was performed on a thermocycler under the following conditions: $5 \mathrm{~min}$ at $94^{\circ}$, followed by 35 cycles of $30 \mathrm{~s}$ at $94^{\circ}, 30 \mathrm{~s}$ at $55^{\circ}$ and $30 \mathrm{~s}$ at $72^{\circ}$, and a final step of $10 \mathrm{~min}$ at $72^{\circ}$. After agarose gel purification and restriction enzyme digestion (with $B a m H I$ and XhoI), the PCR products were inserted into the cloning sites of the expression vector pGEX-6p-1 (Invitrogen, USA). The resulting recombinant plasmid was verified by enzyme digestion and DNA sequencing.

Expression and Identification of Truncated ORF2 Genes

Four confirmed recombinant plasmids (pGEX-Cap A, B, C and D) were transformed in Escherichia coli BL21 cells for expression. After shaking of the cell cultures for $1 \mathrm{~h}, 1 \mathrm{mM}$ of isopropylD-thiogalactopyranoside (Pharmacia Biosciences) was added to 
Table 1. Primers for amplification of truncated forms of PCV2 ORF2 gene by PCR

\begin{tabular}{llc}
$\begin{array}{l}\text { Fragment } \\
\text { names }\end{array}$ & Primer sequence & $\begin{array}{c}\text { Position of the amplified } \\
\text { fragments in ORF2 }\end{array}$ \\
\hline Cap A & 5' -CTGGGATCCATGACGTATCCAAGGAGGCGTTA-3' & \\
& 5' -CCGCTCGAGTCACGTTTTGATGTGGTTCGCTT-3' & nt 1-192 \\
Cap B & 5'-CTGGGATCCACCTTCGGATATACTATCAAGCG-3' & \\
& 5' -CCGCTCGAGTCATGTGGCCTTTGTTACAAAGTTA-3' & nt 154-402 \\
Cap C & 5'-CTGGGATCCGTTAAGGTTGAATTCTGGCCCTG-3' & \\
Cap D & 5'-CCGCTCGAGTCACAGCTGATTTCTTTTGTTGTTTG-3' & nt 301-549 \\
& 5'-CTGGGATCCGTCCTAGATTCCACTATTGATT-3' & \\
& 5'-CCGCTCGAGTCAAGGGTTAAGTGGGGGGTCTTTA-3' & nt 496-699 \\
\hline
\end{tabular}

Table 2. Design of synthesized aa sequence of the truncated Cap A fragment

\begin{tabular}{ll}
\hline Peptide names & Peptide sequence \\
\hline Cap A-a & TYPRRRYRRRRHRPRGHLGQILRRR \\
Cap A-b & ILRRRPWLVHPRHRYRWRRKNGTFN \\
Cap A-c & KNGTFBPRLSRTFGYTIKRTTVKT \\
Cap A-b-1 & ILRRRPWLVHPRHRY \\
Cap A-b-2 & PRHRYRWRRKNGTFN \\
\hline
\end{tabular}

Table 3. Design of synthesized aa sequence of truncated Cap A-b1 fragment

\begin{tabular}{lcc}
\hline $\begin{array}{l}\text { Peptide } \\
\text { names }\end{array}$ & Peptide sequence & $\begin{array}{l}\text { Peptide } \\
\text { position }\end{array}$ \\
\hline Cap A-b-1-1 & RRRPWLVHPRHRYRW & aa 24-38 \\
Cap A-b-1-2 & $\underline{\text { RPWLVHPRHRYRWRR }}$ & aa 26-40 \\
Cap A-b-1-3 & $\frac{\text { WLVHPRHRYRWRRKN }}{\text { VHPRHRYRWRRKNGT }}$ & $\begin{array}{l}\text { aa } 28-42 \\
\text { aa } 30-44\end{array}$ \\
Cap A-b-1-4 & GQILRRRPWLVHPRH & aa 20-34 \\
Cap A-b-1-5 & HLGQILRRRPWLVHP & aa 18-32 \\
Cap A-b-1-6 & RGHLGQ $\underline{\text { alLRRPWLV } 16-30}$ \\
Cap A-b-1-7 & aa 14-28 \\
Cap A-b-1-8 & RPRGHLGQILRRRPW & \\
\hline
\end{tabular}

Luria-Bertani broth and the cultures were then agitated for a further $4 \mathrm{~h}$. The bacterial cells were pelleted at $5,000 \mathrm{~g}$ for $15 \mathrm{~min}$ and lysed by sonication in PBS (pH 7.4). The expression of fusion proteins was confirmed by Western blot analysis with the porcine polyclonal antibody against PCV2-rCap.

Western Blot Analysis

Cell lysates were mixed with an equal volume of sample loading buffer (50 mM Tris- $\mathrm{HCl}, \mathrm{pH} 6.8,100 \mathrm{mM}$ dithiothreitol, 2\%
SDS, $0.1 \%$ bromophenol blue and $10 \%$ glycerol) and separated by SDS-PAGE on $12 \%$ polyacrylamide gels. For immunoblotting, the proteins were transferred from the polyacrylamide gel to nitrocellulose membrane. Nonspecific antibody binding sites were blocked with $1 \%$ nonfat milk in PBS-T (PBS plus $0.5 \%$ Tween-20) overnight at $4^{\circ}$. The membranes were then incubated with the primary antibody at $37^{\circ}$ for $1 \mathrm{~h}$. After incubation with the primary antibody, the membrane was washed 3 times with PBS-T (5 min each time). The blot was then probed with a 1:5,000 dilution of HRP-conjugated goat anti-mouse IgG (Sigma-Aldrich) secondary antibody for $1 \mathrm{~h}$ at $37^{\circ}$. Finally, the membrane was washed 3 times with PBS-T and immunoreactivity was visualized using the substrate diaminobenzidine (Sigma-Aldrich).

Preliminary Determination of the Epitopes Expressed on the Truncated Cap A Fragment

After preliminary location of the epitopes using the truncated Cap proteins, 3 peptides spanning the entire Cap A fragment deduced from PCV2-JF strain were designed and synthesized (GL Biochem, Shanghai, China). Adjacent peptides had 5 or 6 aa residues in common and were termed Cap A-a, -b and -c (table 2). The peptides were screened by indirect ELISA. Briefly, an ELISA plate was coated with the synthesized peptides $(1 \mu \mathrm{g}$ per well) and incubated overnight. The plate was then blocked with $1 \%$ nonfat milk for $1 \mathrm{~h}$ at $37^{\circ}$. After 3 washes with PBS-T, $100 \mu \mathrm{l}$ of hybridoma supernatant containing $\mathrm{mAbs}$ was added to each well and incubated at $37^{\circ}$ for $1 \mathrm{~h}$. Following 3 further washes with PBS-T, the bound $\mathrm{mAb}$ were detected with a 1:5,000 dilution of HRP-conjugated goat anti-mouse IgG (Sigma-Aldrich). After further washes with PBS-T, $100 \mu$ of 2,2'-azino-bis(3-ethylbenzthiazoline-6-sulfonic acid) was added. The reaction was stopped after 30 min with $2 \mathrm{M} \mathrm{H}_{2} \mathrm{SO}_{4}$ and the absorbance at 405 $\mathrm{nm}$ was measured using an ELISA plate reader (Bio-Rad, Hercules, Calif., USA). All samples were analyzed in duplicate and the results are presented as the average of these readings. Based on the results, 2 other peptides spanning the Cap A-b region (Cap A-b-1 and -2) were subsequently synthesized (table 2 ) and shared 5 aa residues. These peptides were used for further mapping of the epitopes and were screened using the ELISA method described above. 
Precise Epitope Mapping

According to the results of ELISAs, the overlapping fragment of Cap A-b-1 (22ILRRRPWLVHPRHRY ${ }^{36}$ ) was truncated by sequentially removing 2 aa from each end. The resulting truncated peptides (designated Cap A-b-1-1 to Cap A-b-1-8) were screened by ELISA as described above (table 3 ). The immunoreactivity of the artificial peptides was confirmed using PCV2-positive pig sera, and we tested whether the epitope could be recognized by the immune system using an ELISA method similar to that mentioned above.

\section{Results}

Amplification of Truncated ORF2 Genes and Identification of Recombinant Expression Vectors

Four truncated fragments of the ORF2 gene were amplified from the DNA of strain PCV2-JF (data not shown). These PCR products were then inserted into the cloning sites (BamHI and XhoI) of the expression vector pGEX-6p-1. The desired recombinant plasmid was verified by enzyme digestion and DNA sequenc-ing.

\section{Expression of Truncated ORF2 Proteins and}

\section{Localization of Antigenic Epitopes}

Four truncated proteins were expressed as GST fusions, separated by SDS-PAGE and identified by Western blot analysis with a porcine polyclonal antibody to PCV2rCap. The truncated proteins $(\sim 34 \mathrm{kDa})$ all showed strong reactivity to the porcine polyclonal antibody (fig. 2). The protein expressed by the pGEX-6p-1 vector $(\sim 28 \mathrm{kDa})$ showed no reactivity and served as the negative control. These 4 proteins displaying antigenic epitopes were identified by 5 mAbs (6F10, 5F2, 3A10, 2E8 and 1D2). Western blot results showed that the truncated Cap A protein was recognized by $4 \mathrm{mAbs}$ (6F10, 5F2, $3 \mathrm{~A} 10$ and 2E8) and $\mathrm{mAb} 1 \mathrm{D} 2$ did not react with any of the truncated proteins, except the whole Cap protein expressed by recombinant insect baculovirus (fig. 3).

\section{Localization of the mAb Epitopes in the Truncated}

\section{Cap A Protein}

To locate the linear antigenic epitopes within the Cap A protein, 3 overlapping peptides were synthesized and probed by $4 \mathrm{mAbs}$ (6F10, 5F2, 3A10 and 2E8). ELISA results showed that the Cap A-b peptide was recognized by all 4 mAbs. Each peptide was 24 or 25 aa in length and overlapped by 5 or 6 aa with the neighboring peptides, indicating that the linear epitope was located in the Cap A-b peptide and the adjacent peptides showed no antigenicity to these mAbs (fig. $4 a$ ).

Identification of a New Antigen Epitope in the NLS Region of PCV2 Protein

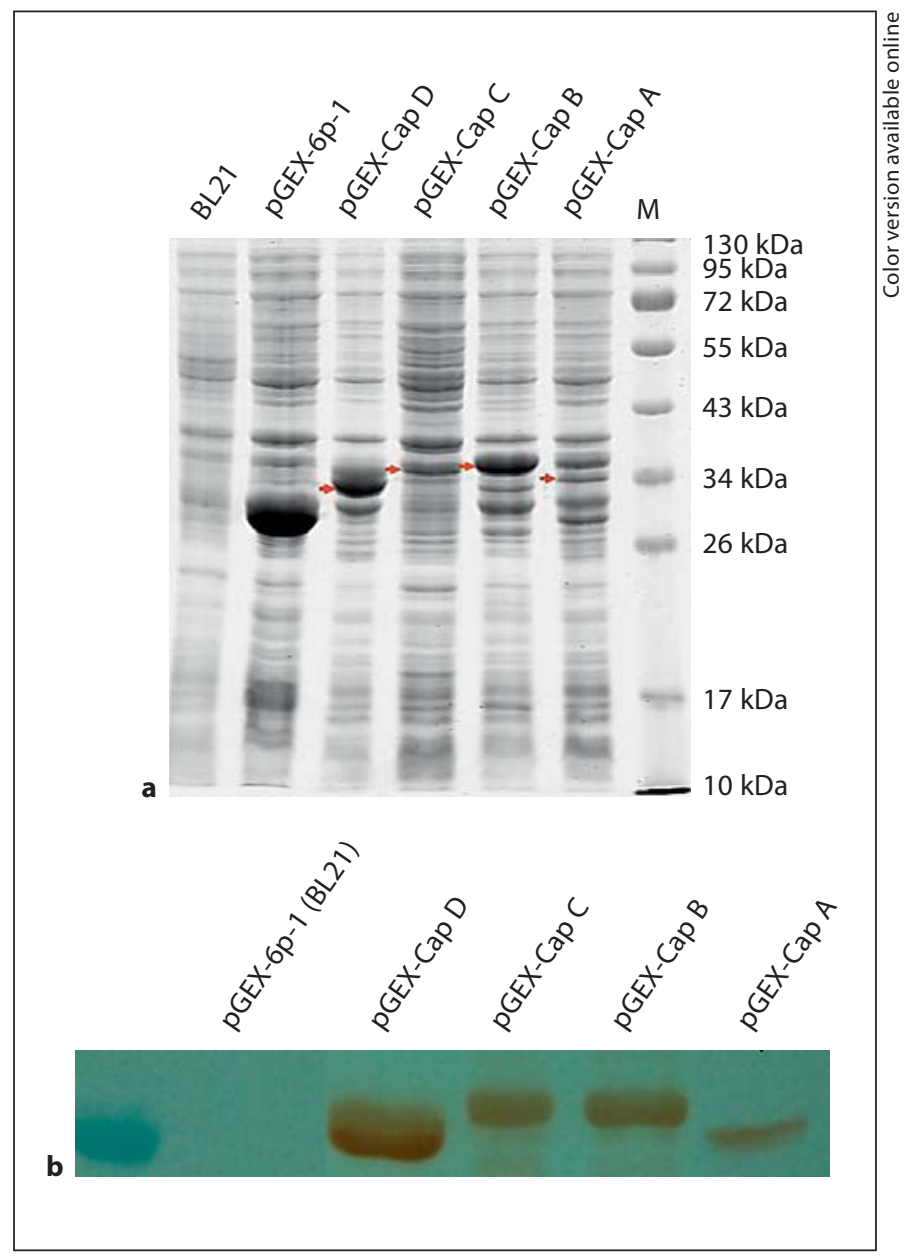

Fig. 2. Identification of the expression of recombinant fusion proteins by SDS-PAGE and Western blot analysis. SDS-PAGE of the recombinant fusion proteins, together with the vector only and the E. coli BL21 cells as controls, was performed and the gel was silver stained to visualize the band corresponding to the recombinant protein (indicated by arrows in a). The 4 truncated proteins $(\sim 34 \mathrm{kDa})$ were all strongly reactive with the porcine polyclonal antibody (b). The pGEX-6p-1 vector $(\sim 28 \mathrm{kDa})$ was included as a negative control.

To further elucidate the position of the linear antigenic epitope within the Cap A-b peptide, 2 overlapping peptides were synthesized and probed by $4 \mathrm{mAbs}(6 \mathrm{~F} 10,5 \mathrm{~F} 2$, $3 \mathrm{~A} 10$ and 2E8). ELISA results showed that the Cap A-b-1 peptide was recognized by all 4 of these $m A b s$, indicating that the linear epitope was located in the Cap A-b-1 peptide (fig. 4a).

Intervirology 2011;54:156-163 


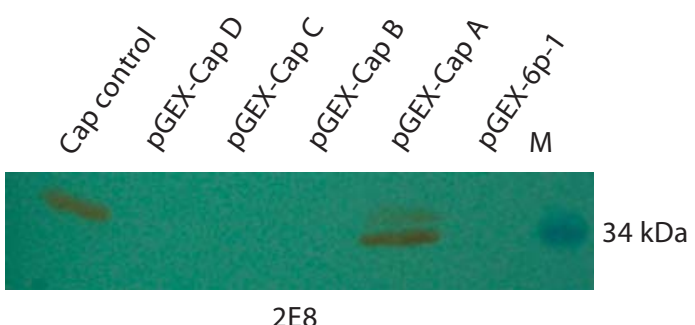

$2 \mathrm{E} 8$

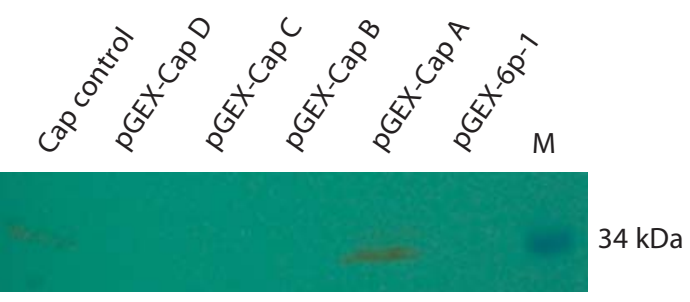

$5 F 2$
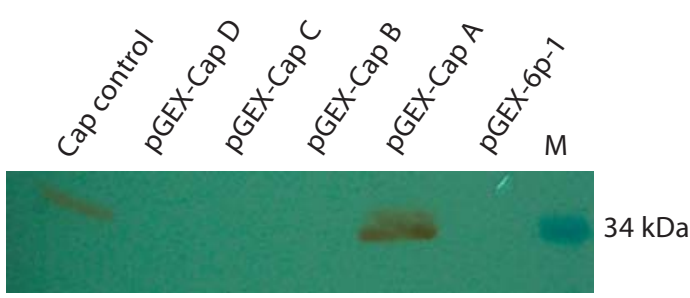

$6 \mathrm{~F} 10$

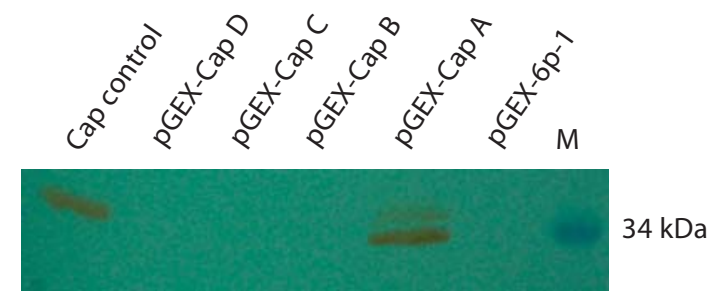

$3 \mathrm{~A} 10$
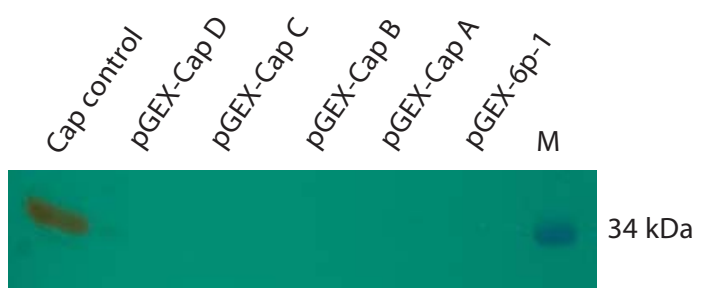

$1 \mathrm{D} 2$

Fig. 3. Detection of the reactivity of $5 \mathrm{mAbs}(6 \mathrm{~F} 10,5 \mathrm{~F} 2,3 \mathrm{~A} 10,2 \mathrm{E} 8$ and 1D2) to the overlapping peptides covering the length of the PCV2 Cap protein by Western blot analysis. Truncated recombinant proteins were analyzed along with the purified Cap protein expressed by Sf21 cells and the expression vector only as positive and negative controls, respectively. Of the $5 \mathrm{mAbs}$ analyzed, 4 $(6 \mathrm{~F} 10,5 \mathrm{~F} 2,3 \mathrm{~A} 10$ and $2 \mathrm{E} 8)$ only showed reactivity with the pGEX-
Cap A fragment and the Cap-positive control whereas mAb 1D2 showed no reactivity with any truncated fragments and only reacted with the Cap-positive control. The results indicate that the epitopes against the $4 \mathrm{mAbs}$ may be located in the truncated fragment pGEX-Cap A and the remaining 1D2 may be a conformational epitope based on its neutralizing effect against PCV2 (data not shown).
Fig. 4. ELISAs to determine the antigenic epitopes on the PCV2 Cap protein. a Detection of the reactivity of $4 \mathrm{mAbs}$ with 5 peptides from the Cap A region by indirect ELISA. Ninety-six-well microtiter plates were coated with synthesized overlapping peptides. After blocking with nonfat milk, mAbs $(6 \mathrm{~F} 10,5 \mathrm{~F} 2,3 \mathrm{~A} 10$ and $2 \mathrm{E} 8)$ were added, followed by the addition of secondary antibody, HRP-conjugated goat anti-mouse IgG. Synthesized overlapping peptides were then detected with the $4 \mathrm{mAbs}$. The results showed that the epitopes to the $4 \mathrm{mAbs}$ were located in the truncated fragment Cap $\mathrm{A}-\mathrm{b}$, and further identification indicated that they were more specifically located in the mimic truncated fragment Cap A-b-1. b Determination of the minimal unit of the epitope by ELISA. A series of truncated peptides (Cap A-b-1-1 to 8) derived from the
Cap A-b-1 peptide were synthesized and subjected to ELISA to locate the minimal unit of the epitope required for recognition by the $4 \mathrm{mAbs}$. Removal of more than 4 aa residues from the $\mathrm{N}$ terminus of the Cap A-b-1 peptide, and as long as removal of 1 aa residue from $\mathrm{C}$ terminus of Cap A-b-1 peptide, resulted in no reactivity with the mAbs. The minimal epitope for the mAbs therefore comprised 11-aa residues: ${ }^{26}$ RPWLVHPRHRY ${ }^{36}$. c Detection of the 11aa peptide $\left({ }^{26} \mathrm{RPWLVHPRHRY}{ }^{36}\right)$ with the $4 \mathrm{mAbs}$ the polyclonal PCV2-positive swine sera (together with the SP20 supernatant) and the PCV2-negative swine sera as controls by indirect ELISA. The peptide reacted positively with the $4 \mathrm{mAbs}(6 \mathrm{~F} 10,5 \mathrm{~F} 2,3 \mathrm{~A} 10$ and 2E8) and PCV2-positive swine sera only, indicating that this epitope is recognized by the immune system. 

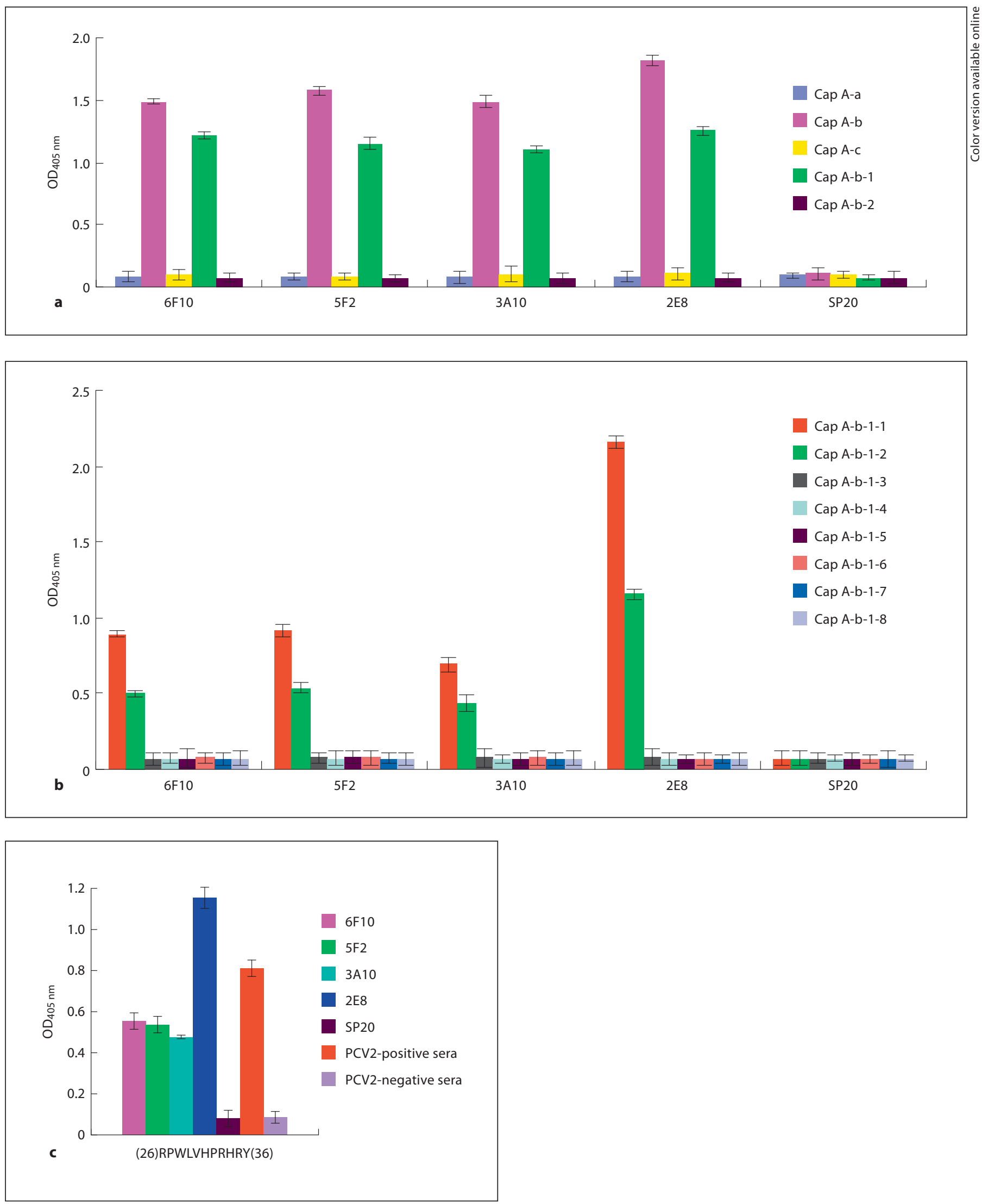
Fine Mapping of the mAb Epitopes in the Truncated Cap A-b-1 Peptide

For further epitope determination, a series of truncated peptides (Cap A-b-1-1 to Cap A-b-1-8) derived from the Cap A-b-1 peptide were synthesized and subjected to ELISA. The results showed that truncation of more than 4 aa residues from the $\mathrm{N}$ terminus of the Cap A-b-1 peptide, and as long as truncation of 1 aa residue from the $\mathrm{C}$ terminus of the Cap A-b-1 peptide, resulted in no reactivity with any of the mAbs. This indicated that the core aa residues comprising the epitope were the same for each $\mathrm{mAb}$, i.e. ${ }^{26}$ RPWLVHPRHRY ${ }^{36}$ (fig. 4b). This epitope was also reactive with the polyclonal PCV2 positive swine sera, confirming that the epitope is recognized by the immune system (fig. 4c).

\section{Discussion}

$\mathrm{mAbs}$ are a powerful tool for identifying linear epitopes or mimic epitopes of proteins and have been used to investigate proteins from a variety of infectious agents [23-25]. Of the $5 \mathrm{mAbs}$ used in this study to investigate the antigenic epitopes of PCV2, 4 recognized the same linear epitope located in the NLS of the N terminus of the Cap protein. The other $\mathrm{mAb}$ did not react with any of the truncated Cap proteins but did react with the whole recombinant Cap protein, which was considered a conformational epitope based on its neutralizing effect against PCV2 (data not shown). The methods used in this study were unable to identify conformational epitopes: other approaches are needed for further elucidation.
To avoid the inhibition caused by the NLS on the expression of recombinant proteins, previous studies on the Cap protein have focused on the protein lacking the NLS $[22,26]$. To date, no studies have effectively verified the epitopes on the NLS, so the function and mechanism of localization of the PCV2 Cap protein remain to be elucidated. In this study, we identified a new epitope located on the NLS, of which 3 aa residues were critical for nuclear localization of the Cap protein. And we can also conclude that this epitope is one of the predominant domains in the Cap protein because the $4 \mathrm{mAbs}$ are against the same epitope. This is the first study to identify an antigenic epitope in the NLS region of the PCV2 Cap protein using $\mathrm{mAbs}$, and our findings will facilitate further studies on the function and mechanism of nuclear localization of this protein. Moreover, mAb 1D2 was strongly active with native PCV2 particles, and could be used to differentiate between PCV1 and PCV2 under the same conditions. So, for further studies, the mAb would be a useful tool for molecular diagnostic and antigen epitope analysis of the virus. And after accurate epitope location for the neutralizing $\mathrm{mAb}$, it would facilitate the development of new vaccines against PCV2.

\section{Acknowledgements}

This work was supported by the National Key Technology R\&D Program (China; No. 2006BAD06A07), grants from the National Science Foundation (China; No. 30871859) and grants from the National Key Laboratory of Veterinary Biotechnology (China; No. NKLVBP200807) and the Chinese Government Foundation for Public Welfare Research Institute (2007-2008).

\section{References}

-1 Tischer I, Bode L, Peters D, Pociuli S, Germann B: Distribution of antibodies to porcine circovirus in swine populations of different breeding farms. Arch Virol 1995;140: 737-743.

-2 Allan G, Meehan B, Todd D, Kennedy S, Mcneilly F, Ellis J, Clark EG, Harding J, Espuna E, Botner A, Charreyre C: Novel porcine circovirus from pigs with wasting disease syndromes. Vet Res 1998;142:467-468.

3 Ellis J, Hassard L, Clark E, Harding J, Allan G, Willson P, Strokappe J, Martin K, Mcneilly F, Meehan B, Todd D, Haines D: Isolation of circovirus from lesions of pigs with postweaning multisystemic wasting syndrome. Can Vet J 1998;39:44-51.
4 Mankertz A, Domingo M, Folch JM, Le Cann P, Jestin A, Segales J, Chmielewicz B, Plana-Duran J, Soike D: Characterization of PCV2 isolates from Spain, Germany and France. Virus Res 2000;66:65-77.

$\checkmark 5$ Zhou JY, Chen QX, Ye JX, Shen HG, Chen TF, Shang SB: Serological investigation and genomic characterization of PCV2 isolates from different geographic regions of Zhejiang province in China. Vet Res Commun 2006;30:205-220.

6 Allan GM, McNeilly F, Kennedy S, Daft B, Clark EG, Ellis JA, Haines DM, Meehan BM, Adair BM: Isolation of porcine circoviruslike viruses from pigs with a wasting disease in the USA and Europe. J Vet Diagn Invest 1998;10:3-10.
7 Mankertz A, Hillenbrand B: Replication of porcine circovirus type 1 requires two proteins encoded by the viral rep gene. Virology 2001;279:429-438.

$\checkmark 8$ Cheung AK: Transcriptional analysis of porcine circovirus type 2. Virology 2003;305: 168-180.

-9 Mankertz A, Mueller B, Steinfeldt T, Schmitt C, Finsterbusch T: New reporter gene-based replication assay reveals exchangeability of replication factors of porcine circovirus types 1 and 2. J Virol 2003;77:9885-9893.

10 Nawagitgul P, Morozov I, Bolin SR, Harms PA, Sorden SD, Paul PS: Open reading frame 2 of porcine circovirus type 2 encodes a major capsid protein. J Gen Virol 2000;81:22812287. 
-11 Wellenberg GJ, Stockhofe ZN, Boersma WJ, De Jong MF, Elbers ARW: The presence of co-infections in pigs with clinical signs of PMWS in the Netherlands: case-control study. Res Vet Sci 2004;77:177-184.

12 Liu J, Chen I, Kwang J: Characterization of a previously unidentified viral protein in porcine circovirus type 2-infected cells and its role in virus-induced apoptosis. J Virol 2005; 79:8262-8274.

13 Liu J, Chen I, Du Q, Chua H, Kwang J: The ORF3 protein of porcine circovirus type 2 is involved in viral pathogenesis in vivo. J Virol 2006;80:5065-5073.

14 Liu Q, Tikoo SK, Babiuk LA: Nuclear localization of the ORF2 protein encoded by porcine circovirus type 2. Virology 2001;285: 91-99.

15 Mahe D, Blanchard P, Truong C, Arnauld C, Le-Cann P, Cariolet R, Madec F, Albina E, Jestin A: Differential recognition of ORF2 protein from type 1 and type 2 porcine circovirus and identification of immunorelevant epitopes. J Gen Virol 2000;81:1815-1824.

- 16 Fenaux M, Opriessnig T, Halbur PG, Elvinger F, Meng XJ: A chimeric porcine circovirus (PCV) with the immunogenic capsid gene of the pathogenic PCV type 2 (PCV2) cloned into the genomic backbone of the nonpathogenic PCV1 induces protective immunity against PCV2 infection in pigs. J Virol 2004;78:6297-6303.
7 Fenaux M, Opriessnig T, Halbur PG, Elvinger F, Meng XJ: Two amino acid mutations in the capsid protein of type 2 porcine circovirus (PCV2) enhanced PCV2 replication in vitro and attenuated the virus in vivo. J Virol 2004;78:13440-13446.

18 Timmusk S, Fossum C, Berg M: Porcine circovirus type 2 replicase binds the capsid protein and an intermediate filament-like protein. J Gen Virol 2006;87:3215-3223.

19 Truong C, Mahe D, Blanchard P, Le-Dimna M, Madec F, Jestin A, Albina E: Identification of immunorelevant ORF2 epitope from porcine circovirus type 2 as a serological marker for experimental and natural infection. Arch Virol 2001;146:1197-1211.

20 Lekcharoensuk P, Morozov I, Paul PS, Thangthumniyom N, Wajjawalku W, Meng $\mathrm{XJ}$ : Epitope mapping of the major capsid protein of type 2 porcine circovirus (PCV2) by using chimeric PCV1 and PCV2. J Virol 2004;78:8135-8145.

-21 Lefebvre DJ, Costers S, Van-Doorsselaere J, Misinzo G, Delputte PL, Nauwynck HI: Antigenic differences among porcine circovirus type 2 strains, as demonstrated by the use of monoclonal antibodies. J Gen Virol 2008;89: 177-187.
22 Shang SB, Jin YL, Jiang XT, Zhou JY, Zhang $X$, Xing G, He JL, Yan Y: Fine mapping of antigenic epitopes on capsid proteins of porcine circovirus and antigenic phenotype of porcine circovirus type 2 . Mol Immunol 2009;46:327-334.

23 Kaverin NV, Rudneva IA, Govorkova EA, Timofeeva TA, Shilov AA, Kochergin-Nikitsky KS, Krylov PS, Webster RG: Epitope mapping of the hemagglutinin molecule of a highly pathogenic H5N1 influenza virus by using monoclonal antibodies. J Virol 2007; 81:12911-12917.

24 O'Nuallain B, Allen A, Ataman D, Weiss DT, Solomon A, Wall JS: Phage display and peptide mapping of an immunoglobulin light chain fibril-related conformational epitope. Biochemistry 2007:46:13049-13058.

25 Thong KL, Tang SS, Tan WS, Devi S: Peptide mimotopes of complex carbohydrates in Salmonella enterica serovar typhi which react with both carbohydrate-specific monoclonal antibody and polyclonal sera from typhoid patients. Microbiol Immunol 2007;51: 1045-1052.

26 Zhou JY, Shang SB, Gong H, Chen QX, Wu JX, Shen HG, Chen TF, Guo JQ: In vitro expression, monoclonal antibody and bioactivity for capsid protein of porcine circovirus type II without nuclear localization signal. J Biotechnol 2005;118:201-211. 